\title{
Optimasi Promosi Produk Menggunakan Media Sosial pada UMKM Binaan PKKP Kabupaten Blora
}

\author{
Candra Irawan ${ }^{1}$, Eko Hari Rachmawanto ${ }^{2}$, Ajib Susanto $^{3}$, Christy Atika Sari ${ }^{4}$ \\ ${ }^{1}$ Program Studi Sistem Informasi, Universitas Dian Nuswantoro \\ ${ }^{2,3,4}$ Program Studi Sistem Informasi, Universitas Dian Nuswantoro \\ E-mail: ${ }^{1}$ candra.irawan@dsn.dinus.ac.id, ${ }^{2}$ eko.hari@dsn.dinus.ac.id, \\ 3ajib.susanto@dsn.dinus.ac.id, ${ }^{4}$ christy.atika.sari@dsn.dinus.ac.id
}

\begin{abstract}
Abstrak
Saat ini produk UMKM yang dihasilkan oleh kelompok usaha atau industry rumah tangga belum dikenal oleh calon pembeli atau pelanggan yang ada di luar daerahnya dikarenakan promosi yang dilakukan hanya dari cerita orang ke orang lain. Beberapa pelaku sudah menggunakan grup-grup di apalikasi chating, media sosial dan jejaring sosial akan tetapi hanya dilakukan tidak rutin dan belum menggunakan cara yang efektif dalam melakukan promosi dan penjualan. Kendala lain yang dihadapi adalah desain kemasan yang dibuat belum mencirikan produk yang dijual dan belum memberikan informasi yang detail tentang produknya sehingga mengurangi daya tarik pembeli. Tujuan dari program pengabdian ini adalah untuk memberikan pelatihan internet marketing dan design packaging untuk UMKM Binaan PKKP Kabupaten Blora sehingga dapat membuat desain kemasan dan melakukan pemasaran online melalui media sosial dan jejaring sosial.
\end{abstract}

Kata kunci: UMKM, Blora, media sosial, jejaring sosial

\begin{abstract}
Currently, UMKM products produced by business groups or home industries are not yet known by prospective buyers or customers who are outside their area because promotions are carried out only from stories of people to other people. Some actors have used groups in chat applications, social media and social networks, but they are only done irregularly and have not used effective means of promoting and selling. Another obstacle faced is that the packaging design that is made does not characterize the product being sold and does not provide detailed information about the product, thereby reducing the attractiveness of the buyer. The purpose of this service program is to provide training in internet marketing and packaging design for PKKP-assisted Blora Regency so that it can create packaging designs and do online marketing through social media and social networks.
\end{abstract}

Keywords: UMKM, Blora, Social Media, Social Networking

\section{PENDAHULUAN}

Data Survei Angkatan Kerja Nasional (Sakernas) Agustus 2019 mencatat adanya penurunan TPAK dari 72,81 di tahun 2018 menjadi 68,35 di tahun 2019. Penurunan TPAK memberikan indikasi adanya potensi ekonomi dari sisi pasokan (supply) tenaga kerja yang juga menurun. Tingkat Pengangguran Terbuka (TPT) merupakan salah satu indikator yang digunakan untuk mengukur tingkat penawaran tenaga kerja yang tidak digunakan atau tidak terserap oleh pasar tenaga kerja. Pada bulan Agustus 2019, tercatat TPT Kabupaten Blora sebesar 3,89\%. Dalam tiga tahun terakhir, TPT Kabupaten Blora terus mengalami peningkatan dimana TPT 2017 terhitung sebesar 2,85\% lalu naik menjadi 3,26\% di tahun 2018 dan kembali naik di tahun 2019. TPT merupakan salah satu masalah dalam pembangunan ekonomi, dan 
perlu dicermati karena dalam jangka panjang akan menimbulkan persoalan sosial ekonomi yang cukup serius. Proporsi terbesar penduduk bekerja di Kabupaten Blora masih berada di sektor pertanian. Meskipun demikian, secara umum proporsinya terus mengalami penurunan dari tahun ke tahun. Di sisi lain, jumlah usia tenaga kerja muda cukup tinggi sehingga terdapat celah untuk mengoptimalkan sumber daya tersebut dnegan tujuan peningkatan ekonomi masyarakat.

Dinas Pemuda, Olahraga dan Pariwisata (Disporapar) Propinsi Jawa Tengah sebagai salah satu instansi pemerintah yang salah satu bagian menangani kepemudaan yang membawahi bidang pemuda dan olahraga di 35 Kabupaten/Kota mempunyai kegiatan untuk kepemudaan salah satunya adalah Program Pengembangan Kepedulian dan Kepeloporan Pemuda (PKKP) yang salah satu tugas penempatan di desa melakukan pembinaaan kelompok usaha pemuda untuk mengembangkan usaha yang sudah dirintis, melakukan pendampingan, pelatihan dan membentuk kelompok usaha pemuda yang mandiri.

Saat ini produk UMKM yang dihasilkan oleh kelompok usaha atau industri rumah tangga belum dikenal oleh calon pembeli atau pelanggan yang ada di luar daerahnya [1] dikarenakan promosi yang dilakukan hanya dari cerita orang ke orang lain [2]. Beberapa pelaku sudah menggunakan grup-grup di apalikasi chating, media sosial dan jejaring sosial akan tetapi hanya dilakukan tidak rutin dan belum menggunakan cara yang efektif dalam melakukan promosi dan penjualan [3]. Kendala lain yang dihadapi adalah desain kemasan yang dibuat belum mencirikan produk yang dijual [4] dan belum memberikan informasi yang detail tentang produknya sehingga mengurangi daya tarik pembeli.

Kelompok Usaha Mikro, Kecil, Menengah (UMKM) di Jawa Tengah tergolong masih berdaya tawar rendah [5]. Banyaknya pengepul dalam rantai distribusi juga menyebabkan UMKM kurang berkembang, selain belum optimalnya penggunaan teknologi untuk mendukung produksi, pemasaran, penjualan maupun pengelolaan keuangannya. Salah satu yang belum dilakukan secara serius adalah pemasaran online melalui media internet atau biasa disebut internet marketing [6] yang jelas untuk kondisi saat ini akan sangat membantu meningkatkan promosi dan penjualan.

Usaha pemuda binaan PKKP Kab. Blora yang menjadi mitra untuk pengabdian masyarakat ini adalah Kub Wanita Mandiri di desa Bulurejo, Banjarejo Kabupaten Blora dengan usaha pengolahan makanan berstandar dan berbahan baku khas daerah. Dalam proses pemasaran dan penjualan masih dilakukan dengan menjual dirumah, dititipkan di warungwarung dan diberbagai komunitas dan grup chating. Selain itu model kemasan yang dibuat masih belum dibuat wadah khusus akan tetapi masih menggunakan plastik yang belum memberikan informasi akan produk yang dijual secara utuh dari komposisi, manfaat serta informasi kontak person yang dapat dihubungi untuk proses pemesanan dan penjualan barang. Sehingga promosi dan penjualan produk cenderung tidak mengalami peningkatan dikarenakan informasi belum tersampaikan ke berbagai daerah. Pemanfaatan marketplace [7] saat ini yang sudah menjamur dan berkembang pesat juga belum dilakukan sehingga pelaku UMKM ini sangat membutuhkan pelatihan bagaimana memanfaatkan marketplace sehingga peningkatan penjualandapat dilakukan.

Berdasarkan kondisi mitra yang dihadapi saat ini Universitas Dian Nuswantoro sebagai salah satu perguruan tinggi yang berbasis dibidang teknologi informasi dan komunikasi berkewajiban menjalin kerjasama dalam melakukan program pengabdian kepada masyarakat secara berkesinambungan melalui sumber daya yang dimiliki yaitu dosen. Sebagai salah satu wujud tri dharma perguruan tinggi membantu mengimplementasikan internet marketing dan design packaging untuk pelaku UMKM Binaan PKKP Kabupaten Blora untuk meningkatkan promosi dan penjualan produk dengan menggunakan media sosial dan jejaring sosial.

\section{METODE}

Pelaksanaan kegiatan pengabdian masyarakat ini akan dilakukan dalam beberapa tahap, meliputi persiapan dan pelaksanaan. Tahap persiapan, tahap persiapan yang dilakukan dalam melaksanakan kegiatan ini meliputi : (1) Pembuatan proposal kegiatan pengabdian dan 
menyelesaikan administrasi perijinan/surat kerjasama dengan mitra pengabdian; (2) Diskusi antara tim pengabdian dengan mitra mengenai waktu, tempat, sarana prasarana yang dibutuhkan untuk pelaksanaan kegiatan ini; (3) Sosialisasi, pembuatan dan penyebaran informasi kepada mitra untuk pelaksanaan pengabdian ini. Sedangkan pada tahap pelaksanaan, kegiatan ini akan dibagi menjadi tiga tahap antara lain persiapan materi, pelatihan dan pemantauan. Tahap pembuatan materi, dilakukan dengan pembuatan materi untuk pelatihan internet marketing dan pembuatan materi untuk design packaging. Tahap pelatihan yaitu menggunakan Internet Marketing dan Design Packaging. Tahap pemantauan dilakukan untuk mengevaluasi internet marketing dan design packaging yang sedang berjalan. Rapa terakhir yaitu tahap akkhir antara lain pembuatan laporan hasil kegiatan pengabdian, pengumpulan laporan hasil kegiatan pengabdian dan mengevaluasi seluruh kegiatan serta menyempurnakannya berdasarkan masukan-masukan dari berbagai pihak. Secara singkat tahapan dalam kegiatan pengabdian ini dapat dilihat pada Gambar 1.

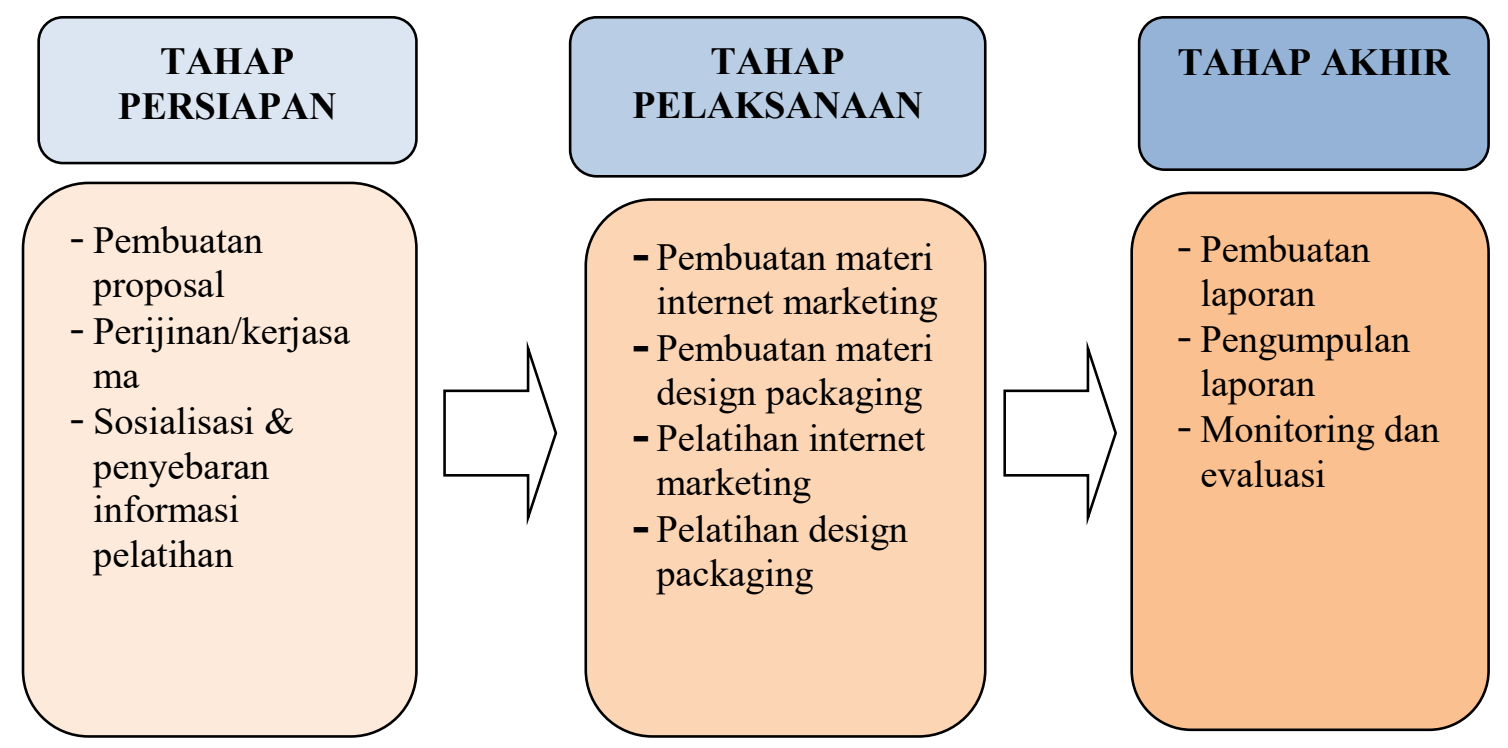

Gambar 1. Tahapan Pengabdian Masyarakat

\section{HASIL DAN PEMBAHASAN}

Kegiatan pengabdian di PPKP Kabupaten Blora tidak dapat dilakukan secara tatap muka karena pandemi Covic-19, sehingga proses dikusi, Forum Group Discussiobn (FGD), serta proses kegiatan pengabdian lainnya telah dilakukan secara daring melalui Google Meet dan Video Call Whatsaap. Berikut ini merupakan materi webinar dengan mitra yang telah terlaksana. 


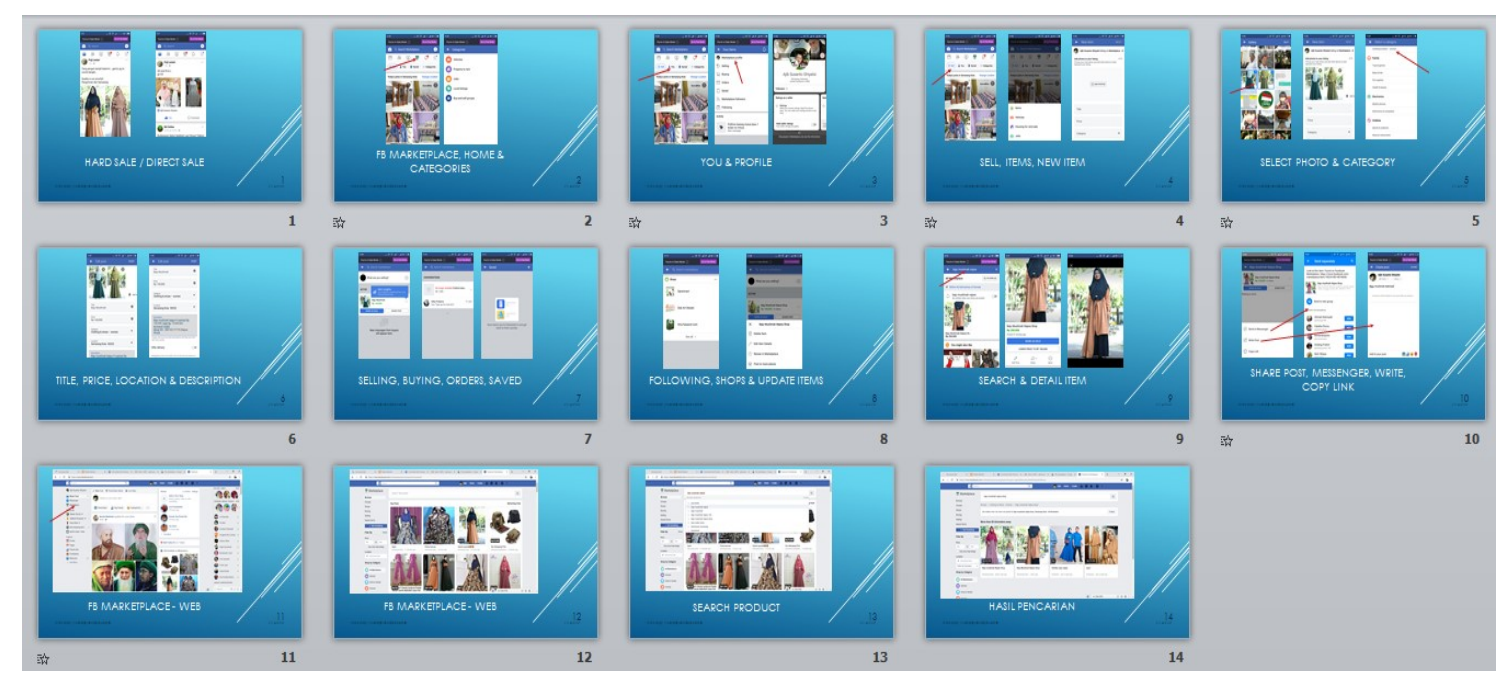

Gambar 2. Materi Webinar

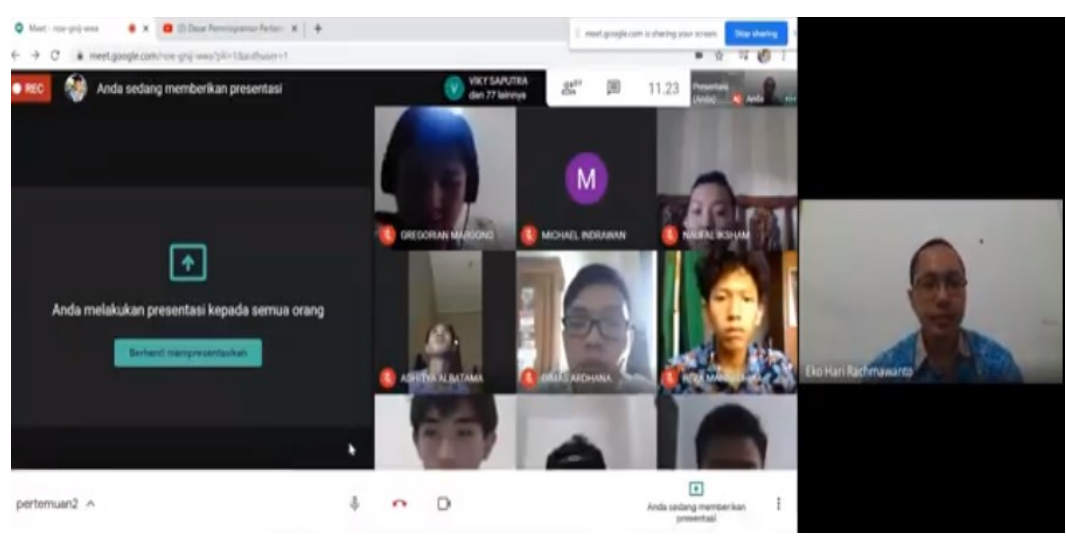

Gambar 3. Proses Webinar dengan Mitra

Setelah webinar dengan mitra terlaksana, dilakukan proses pemantaan kegiatan UMKM mitra. Kegiatan pemantauan meliputi analisa perkembangan income pada hasil penjualan produk dalam satu bulan. Pada bulan berikutnya, kami selaku tim pengabdi melakukan proses perombakan pckaging produk dengan tujuan meningkatkan daya beli masyarakat.

Salah satu desain yangtelah selesai dibuat dan telah diuji coba yaitu milik salah satu anggota UMKM milik Ibu Imelda dengan produk penjualan berupa alat ibadah dan baju muslim. Beliau merupakan anggota UMKM yang sudah bergabung lebih dari 3 tahun dan menunjukkan kapabilitasnya dalam hal penjualan baju muslim secara online. Awal mulanya Beliau menggunakan media Whatsaap saja karena adanya keterbatasan ilmu pengetahuan dan untuk menekan biaya promosi. Mitra juga dibekali dengan informasi dan didampingi untuk membuat akun instagram. Berikut adalah akun instagram yang telah dibuat. 

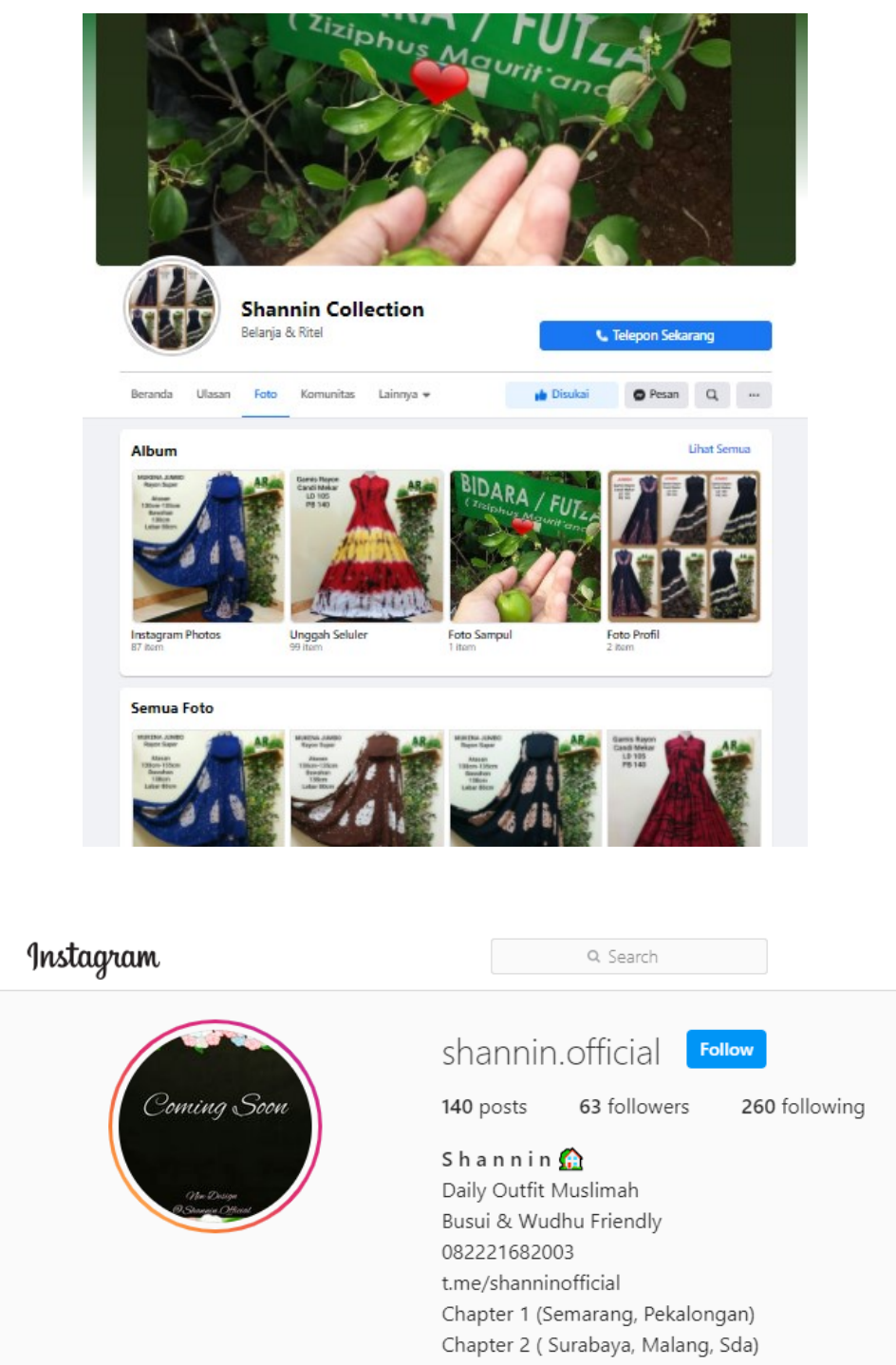

Gambar 4. Instagram dan Facebook sebagai salah satu alat promosi

Berdasarkan analisa dan observasi hasil penjualan produk pada tahap moitoring, diketahui bahwa pendapatan yang didapat telah meningkat. Peningkatan pendapatan dari bulan lalu sudah mencapai Rp. 800.000,- dengan porsi merupakan laba bersih. Untuk lebih meningkatkan pendapatan, akan dilakukan desain logo, desain kemasan produk dan pembuatan website pribadi.

\section{KESIMPULAN DAN SARAN}

Pelaksanaan kegiatan pengabdian dilakukan dalam 3 (tiga) tahap, yaitu tahapan persiapan yang meliputi persiapan ijin, waktu, tempat, dan sosialisasi program, tahapan pelaksanaan yang terdiri atas pembuatan materi, pelatihan internet marketing dan design packaging serta pada tahapan akhir meliputi penyusunan dan pembuatan laporan serta monitoring dan evaluasi kegiatan pengabdian ini. Dengan adanya program pengabdian ini diharapkan mitra dapat meningkatkan promosi dengan desain kemasan yang menarik dan penjualan produk usaha pemuda binaan PKKP Kab. Blora yang mampu dikenal oleh pelanggan dan meningkatkan hasil penjualan yang tidak hanya di lingkungan atau daerah tempat usaha saja akan tetapi dapat meluas tanpa batas karena menggunakan media sosial dan jejaring sosial. 


\section{DAFTAR PUSTAKA}

[1] Rachmawati Rachmawati, "Strategi Komunikasi Pemasaran Produk Pesanan Oleh-Oleh Nusantara (Pesona) PT Tiki JNE Melalui Media Sosial Instagram (Studi Analisis Deskriptif).," Jakarta, 2018.

[2] Ajib Susanto and Ibnu Utomo W Mulyono, "Rekayasa E-Market Untuk Kelompok Usaha Pemuda Binaan Dinas Pemuda Dan Olahraga Propinsi Jawa Tengah Sebagai Upaya Peningkatan Pemasaran Dan Penjualan Produk UMKM," in Prosiding SNATIF, Kudus, 2014, pp. 251-258.

[3] Arif Rahman Iik and Redi Panuju, "STRATEGI KOMUNIKASI PEMASARAN PRODUK FAIR N PINK MELALUI MEDIA SOSIAL INSTAGRAM," Jurnal Wacana, pp. 214-224, 2017.

[4] Ajib Susanto, Christy Atika Sari, Eko Hari Rachmawanto, and Ibnu Utomo W Mulyono, "Implementasi Facebook Marketplace untuk Produk UMKM sebagai Upaya Peningkatan Pemasaran dan Penjualan Online," ABDIMASKU: JURNAL PENGABDIAN MASYARAKAT, pp. 42-51, 2020.

[5] Bayu Ardi Isnanto. (2019, Juli) Detik News. [Online]. https://news.detik.com/berita-jawa-tengah/d4611356/daya-tawar-rendah-umkm-di-jateng-didorong-bentuk-koperasi

[6] Novi Tri Hariyanti and Alexander Wirapraja, "Pengaruh Influencer Marketing Sebagai Strategi Pemasaran Digital Era Moderen (Sebuah Studi Literatur)," Eksekutif, pp. 133-146, 2018.

[7] Ajib Susanto, Wijanarto Wijanarto, Ibnu Utomo W Mulyono, Imam Imam, and Erwin Erwin, "REKAYASA M-MARKET (MOBILE MARKET) UNTUK KELOMPOK USAHA PEMUDA BINAAN DINAS PEMUDA DAN OLAHRAGA PROPINSI JAWA TENGAH SEBAGAI UPAYA PENINGKATAN PENJUALAN PRODUK UMKM," Techno. Com, pp. 8-15, 2015. 